OPEN ACCESS

Edited by:

Bin Wang,

Chinese Academy of Fishery Sciences (CAFS), China

Reviewed by: Xu-Fang Liang, Huazhong Agricultural

University, China

Qiong Zhi Li,

Sichuan Agricultural University, China

*Correspondence:

Huapu Chen

chpsysu@hotmail.com

Specialty section: This article was submitted to Experimental Endocrinology, a section of the journal

Frontiers in Endocrinology

Received: 20 October 2021 Accepted: 18 November 2021 Published: 15 December 2021

Citation: Assan D, Huang Y, Mustapha UF, Addah MN, Li G and Chen H (2021) Fish Feed Intake, Feeding Behavior, and the Physiological Response of Apelin to Fasting and Refeeding.

Front. Endocrinol. 12:798903. doi: 10.3389/fendo.2021.798903

\section{Fish Feed Intake, Feeding Behavior, and the Physiological Response of Apelin to Fasting and Refeeding}

\author{
Daniel Assan 1,2,3,4,5, Yanlin Huang 1,2,3,4, Umar Farouk Mustapha ${ }^{1,2,3,4}$, \\ Mercy Nabila Addah' ${ }^{6}$, Guangli $L^{1,2,3,4}$ and Huapu Chen ${ }^{1,2,3,4,5^{*}}$

\begin{abstract}
1 Fisheries College, Guangdong Ocean University, Zhanjiang, China, ${ }^{2}$ Guangdong Research Center on Reproductive Control and Breeding Technology of Indigenous Valuable Fish Species, Guangdong Ocean University, Zhanjiang, China,

${ }^{3}$ Guangdong Provincial Engineering Laboratory for Mariculture Organism Breeding, Zhanjiang, China, ${ }^{4}$ Guangdong Provincial Key Laboratory of Pathogenic Biology and Epidemiology for Aquatic Economic Animals, Zhaniiang, China,

${ }^{5}$ Southern Marine Science and Engineering Guangdong Laboratory, Zhanjiang, China, ${ }^{6}$ Department of Fisheries and Aquatic Resources Management, Faculty of Bioscience, University for Development Studies, Tamale, Ghana
\end{abstract}

Feed is one of the most important external signals in fish that stimulates its feeding behavior and growth. The intake of feed is the main factor determining efficiency and cost, maximizing production efficiency in a fish farming firm. The physiological mechanism regulating food intake lies between an intricate connection linking central and peripheral signals that are unified in the hypothalamus consequently responding to the release of appetite-regulating genes that eventually induce or hinder appetite, such as apelin; a recently discovered peptide produced by several tissues with diverse physiological actions mediated by its receptor, such as feed regulation. Extrinsic factors have a great influence on food intake and feeding behavior in fish. Under these factors, feeding in fish is decontrolled and the appetite indicators in the brain do not function appropriately thus, in controlling conditions which result in the fluctuations in the expression of these appetiterelating genes, which in turn decrease food consumption. Here, we examine the research advancements in fish feeding behavior regarding dietary selection and preference and identify some key external influences on feed intake and feeding behavior. Also, we present summaries of the results of research findings on apelin as an appetite-regulating hormone in fish. We also identified gaps in knowledge and directions for future research to fully ascertain the functional importance of apelin in fish.

Keywords: apelin, feeding behavior, feed intake, fish, orexigenic

\section{INTRODUCTION}

Food is one of the foremost expenses of intensive fish farming, which fish farmers need to pay much attention to. Its availability in quantity and quality is significant for the appropriate growth and reproduction of fish (1). Feeding as determined by Metcalfe and colleagues (2) plays a vital role in animal life-sustaining activities. Evidence has it that, the regulation of feed intake, as in mammals, is well conserved in vertebrates, including some fish species $(3,4)$. The optimization of food intake can 
lead to enhanced growth and body composition, with increased food conversion efficiency and reduced nutrient losses, which are major objectives in intensive fish farming (1).

The intake of feed is known to be regulated by complex interactions between the brain and peripheral appetite-regulating hormonal factors, including apelin (5). As indicated by Volkoff and colleagues (1), when the endocrine mechanisms controlling food intake in fish is understood, it will not only lead to the explicit modifications in fish-holding situations and feeding approaches such as temperature and time of feeding respectively but rather, it will also help to develop new procedures to improve food conversion efficiency as well as aquaculture growth.

In the past years, less attention has been given to apelin in the regulation of feed intake in vertebrates. With its uncertain role in mammals as a feed intake regulator, apelin has been identified to play an orexigenic role in vertebrates such as fish. It aids in several regulation of biological activities in fish, which most importantly includes the regulation of food consumption. The goal of this review is twofold; firstly, to examine the recent advances in our understanding of the feeding behavior, focusing more on dietary selection and preference of fish as well as analyzing the influence that some external factors have on feed intake and behavior. Secondly, we gather information from previous research studies on apelin, categorizing its specific role in fish as an appetite-regulating hormone and identifying gaps in knowledge and directions for future research regarding this important topic.

\section{FEED INTAKE AND FEEDING BEHAVIOR IN FISH}

The result of food intake is the alteration that lies between starvation, craving, and satiation. Starvation is the physiological necessity for food, including a strong incitement to feeding behavior; looking for food and consuming it. Satiation is the physiological and rational sense of "fullness" that happens after food intake whiles appetite or craving, on the other hand, is the desire to eat, which is commonly related to the material (find, fragrance, taste) perceptiveness of the food to be consumed (6).

Feed is among the most authoritative signals outside the fish's body that can arouse feeding behavior and growth (7-9). Its readiness and composition exert a key control of these processes, by acting principally on the hormones responsible for their endocrine control (9). Some central and peripheral appetite regulators in fishes are affected by a single meal, showing perprandial fluctuations in their expression and/or secretion levels. Such changes in fishes have been identified in the brain hormone $(10-13)$. The search for food and its intake in fish is girded by a series of behavioral acts matched through a supportive work between the nervous and endocrine systems (14). The control of feed ingestion behavior is a remarkable multifaceted development that comprises particularized interactions between the brain and marginal indications (15). The metabolic sensors located in the central nervous system of fishes provide room for the hypothalamic systems to receive nutritional information, allowing a qualitative control of food ingestion (16). The neural effectors of the hypothalamic origin facilitate the control of food consumed by the fish, thus, by integrating between hunger and satiety signals (17) which include apelin and neuropeptide $\mathrm{Y}$ for hunger hints $(18,19)$, and amylin and cocaine-and amphetamine-regulated transcript for satiety hints $(20,21)$. As important as it is, it interests more fisheries and aquaculture firms in curbing fish growth and reproduction by changing food and/or endocrine settings.

Fish feeding behavior is miscellaneous and has been broadly examined in both wild and farmed fish from their ecological perspectives $(22,23)$ whiles behavioral responses of fish to feeding have been associated with feeding approaches, feeding habits, feeding regularity, feed detection mechanisms and feed preferences (24). Feeding behavior and its regulation in fish comprises of external and internal environment information being analyzed by signaling molecules and receptors in the fish. Thus, the hypothalamus, assisted by other brain sections in the fish, integrates inbound indications $(3,14)$. As ascertained by Volkoff and colleagues, changes in dietary behavior and cravings are frequently related to changes in gene expression and/or protein content of the appetite regulators or their receptors. That is to say, changes in the mRNA/protein levels of a given hormone due to starvation or feeding have the probability of reflecting its physiological role in regulating feed ingestion. Nevertheless, it should be noted that, in the view of the multifactorial character of food regulation, there is a probability for compensative mechanisms in the manner or conduct of feeding to take place whiles fluctuations in available hormones might not essentially suggest variations in feed intake (1).

\subsection{Dietary Selection and Preference in Fish}

Fish do not consume all the food items they come across. Dietary selection has been broadly explored in mammals, which lessen their consumption of an imbalanced diet to avoid negative dietary impacts (25). Nourishment choice is based on the preface that animals, such as fish, have "quality dietary insight" and hence, select a diet that optimally restores a metabolic imbalance as a result of a nutritional challenge (26). Fishes are selective in the choice of food that contains the necessary nutrients for their survival, growth, and reproduction. This insinuates that fishes as in other animals have evolved from extraordinary diversity of means and challenges, being able to sense nutrients and the existence of precise hungriness to regulate the intake of specific nutrients (27). The source of nutrients can be recognized by gastrointestinal receptors during food digestion, as they are released interiorly in the stomach and pass into the digestive tract. Those receptors would trigger neural action and hormonal signals that would direct brain centers about the dietary properties of food and subsequently alter feeding behavior $(28,29)$.

Nutrition is a very significant inward factor in fish, as the foremost determination of fish feeding is to satisfy the protein and energy requirements of the fish, relating to feeding behavior 
and feed consumption, and have the probability to unswervingly influence or impact the appetite of the fish, reflecting in its growth (30). Nutrients are biological composites involved in biochemical reactions that produce energy and are ingredients of cellular biomass (31). These nutrients have been categorized into two groups; macronutrients and micronutrients. Macronutrients are those that are required in comparatively large quantities since they are the key source to generate the energy required by organisms to live, grow, and reproduce (32). Micronutrients on the other hand are those needed in smaller quantities, even though they have several significant roles in cellular processes $(33,34)$. The figure below gives examples of key macronutrients and micronutrients and their importance in feed (Figure 1). Detailed information on feed and nutrient requirements for fish can be found in a book from the National Research Council (NRC) (34).

The quality of feed suggests the nutritional efficacy and the objective components of a feed making it pertinent to eat and digestible for the fish (42). Fish growth, good health, and maintenance are achieved only when the precise quantity of energy and vital nutrients are available in their adequate proportions in the feed, aiding in proficient feed intake (43, 44). Response to feed intake, its tastiness, and digestibility differ as a result of the difference in fish feed components (41). Signifying that, fish farmers should access the quality of feed they provide for their fish since it plays a key role in it being accepted by the fish, how appetizing it is, and its digestibility. Similarly, the composition of a diet is an additional nutritional aspect of a feed that needs quality attention since it influences appetite-regulating hormones. While the literature available on this is insufficient as stated by Bertucci and colleagues, several research studies have it that, when macronutrients are changed in the diet composition of the fish, it has a significant impact on either the secretion and/or the expression of appetite-regulating hormones. Thus, it's of great importance in fisheries and aquaculture since fluctuating diet and/or hormone milieu influence fish growth and reproduction (9).

Aside from the use of the 'feed intake' method which has extensively been used in animal nutrition, the use of 'self-feeders' in diet selection could be used as a great means to improve the understanding of the physiological approaches towards feeding behavior in fish. For example, studies on rainbow trout (Oncorhynchus mykiss) revealed that it could differentiate between diets varying in the vital amino acid content. It also showed that the fish had a precise preference for the whole diet over the balanced amino acids (45). Also, research conducted on self-selection of diets in sharp snout seabream (Diplodus puntazzo) and the Senegalese sole (Solea senegalensis) revealed that these species select macronutrients according to their dietary needs $(29,46)$.

According to da Silva and colleagues (27), there are numerous benefits to offering animals a free choice of nourishment, which is considered the most biological and moderate way of providing feed for fish. With time, fish can learn to select specific feeds following their nourishing requirements, as well as self-feed (46, 47). Equally, when the fish meets its goal of each specific nutrient consumption, it will provide its body with the optimal concentrations of nutrients required for proper growth and reproduction $(26,48)$.

\subsection{Extrinsic Factors Influencing Feeding and Feeding Behavior in Fish}

Generally, hunger stimulates the behavioral response of feeding fish. When feed is available, fish may initially feed at a faster rate and slowly decrease or stop with a gradual decline of appetite. Feeding behavior despite being influenced by intrinsic factors is extremely influenced by ecological or extrinsic factors $(1,49,50)$. Below, we highlight some of these environmental factors that influence food ingestion and feeding behaviors in fish.

\subsubsection{Stress}

Stress has been defined as the disturbance of physiological or biological mechanisms due to internal and external factors, which are generally designated as stressors (51). These provoke a cataract of consistent behavioral and biological rejoinders in which a living organism makes efforts to reestablish homeostasis, consequently incapacitating the threat. In an aquaculture firm, cultured fish are restricted, captured, crowded, sedated, held, and transported during repetitive husbandry (51). In consequence, all these taken into consideration are ordinary events in fish farming and they are possible stressors that interrupt the behavioral and biological mechanisms of the organism. Thus, causing a

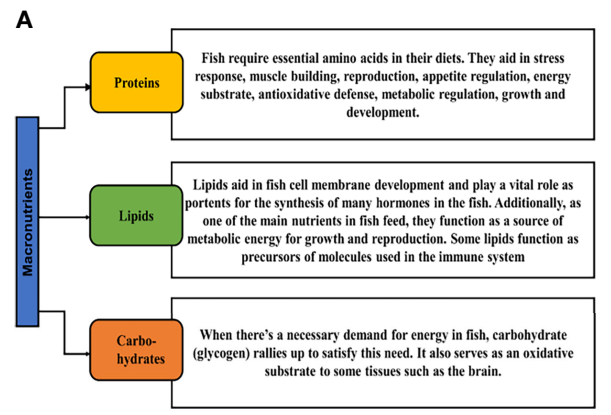

B

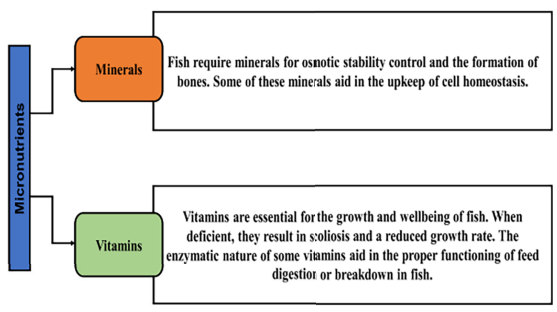

FIGURE 1 | The role and importance of key macronutrients (A) and micronutrients (B) in fish food. Proteins; (9, 32, 35), lipids; (9, 36-38), carbohydrates; (8, 39, 40), minerals; $(9,41)$ and vitamins; (41). 
functional response crucial to recover the dynamic consistency (52). Reduction in feed ingestion has been described to be distinctive behavioral feedback to stress in fish $(53,54)$. Undeniably, stress can also disrupt several feeding conducts in fish, including the food search, finding, or capturing prey $(16,55$, 56 ), leading to a decline in growth in several fish species (54). Fish under stressful conditions as compared to unstressed fish eat less and have slow growth. Even when food intake levels are maintained in fish, these conditions are known to persuade a decline in the conversion efficiency of feed consumed, leading to the decreased growth rate $(57,58)$. For example; a research by Lee and colleagues revealed that acute physical stress caused by cleaning once or thrice a week reduced the daily and cumulative feeding levels and feed conversion efficiency significantly in the sea bass (Dicentrarchus labrax) (59). Furthermore, these stressors have been known to adjust the control of endocrinal growth alliance in fish such as the secretion of pituitary growth hormone, among others (60-62). In the two subsections below, we discussed two key stressors that influence the well-being of fish, which needs keen attention.

\subsubsection{Temperature}

There have been several demonstrations of the relationship that exists between temperature and feeding in several fish species. Temperature is one of the most dominant factors influencing some key biological functions in fish, including feed ingestion and feeding behavior $(63,64)$. Relatively, despite the complex and species-specific effects of temperature in fish, the relation between feeding/feeding behavior and temperature is like a bellshaped structure (65); at normal temperature conditions, the voluntariness of food intake also increases (65) and/or is maintained during the acclimatization period of temperature which is specific to a particular species. On the other hand, when there's a slight decrease in temperature, the fish adapts to the temperature and maintains its feeding rate for a short period. It has also been ascertained that before the ultimate maximal/ minimal critical temperature for a species reaches, it will lose appetite, cease, and lastly stop feeding (66); see Figure 2. Examples given here revealed that, a research conducted on Atlantic cod (Gadus morhua) revealed that, when kept in a water temperature of $2^{\circ} \mathrm{C}$ for four weeks, there was a decrease in feed consumption compared to those kept in $11^{\circ} \mathrm{C}$ and $15^{\circ} \mathrm{C}$ water temperature (67). Also, research conducted on the red-spotted grouper (Epinephelus akaara) revealed that when the water temperature is around $25^{\circ} \mathrm{C}$, there's an increase in its feeding and digestion level (68). However, it should be taken into consideration that when the optimal temperature of a particular fish species reaches and/or exceeds, it results in a gradual decline in feeding behavior $(69,70)$.

\subsubsection{Hypoxia}

Dissolved oxygen (DO) is among the most significant extrinsic factors in fish farming (71). It is known to be a key restrictive factor in aquaculture with the particular reason for the circumstance being that, fish have aerophilic absorption which requires DO at efficient levels (72). The depletion of DO concentration (hypoxia) in water bodies has been identified to be a stern extrinsic stress, which commonly occurs in highdensity aquaculture (73). Reports have indicated that growth, survival, behavior as well as other physiological activities of some fish species are highly influenced by different degrees of hypoxia $(72,74)$ and is also known to be an endocrine disruptor (75).

Fish under severe hypoxia conditions experience reduced movement or feed intake to conserve energy (72). In research conducted on the Atlantic salmon (Salmo salar) with regards to the hypoxic period and its physiological activities, results revealed that there were behavioral changes associated with oxygen shortage and physiological stress in some groups. Also, the severity of hypoxia reduced the intake of feed in the fish (76). In a research study on tilapia (Oreochromis niloticus) it was discovered that fish kept in hypoxic conditions had significantly reduced feed intake, survival rate, and weight gain (71).

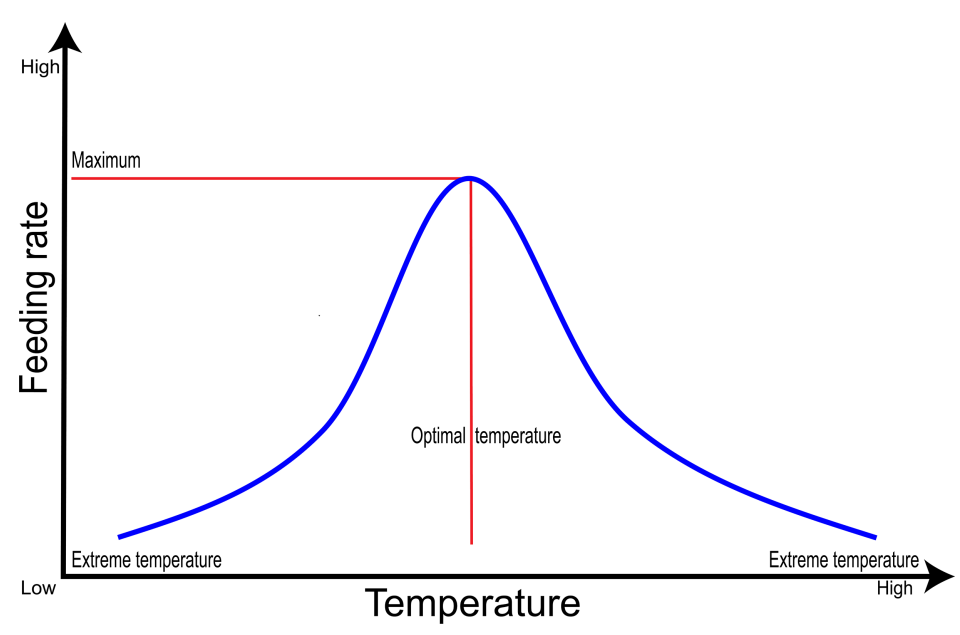

FIGURE 2 | A general relative relation between feeding rate and temperature of fish species. The feeding rate decrease and subsequently stops at higher or lower temperatures (extreme temperatures). 
Additionally, a research study on rainbow trout (Oncorhynchus mykiss) demonstrated that hypoxia reduces feed consumption, growth rate, oxygen consumption, energy, and lipid contents (77). On the other hand, research conducted on tilapia (Oreochromis niloticus) comparing three DO (normal, low and medium) levels showed that, the final fish weight of those in the normal DO levels group were significantly higher as compared to those in the low and medium DO levels groups. Additionally, fish under the low DO level group demonstrated a lower feed intake rate. The low DO level group also revealed that fish in this group had a lower growth and feed utilization rate (78). This significantly demonstrates that when fed under enough DO levels, fish show good efficiency of their feed intake (79), which will most importanlt aid in good feed conversion ratio, fish growth and reproduction in the absence of any other stress. Hypoxia has been discovered to persuade primary, secondary, and tertiary stress responses in fish $(80,81)$. However, most fishes can adapt to the variations in DO levels but if severe hypoxia remains, fish will sooner or later die (82).

Cultured fish always face repetitive and chronic hypoxia stress especially from overcrowding which they can barely escape due to their confined environment. Therefore, it is suggested that DO levels should be checked and highly maintained near the saturation level. In doing so, it enhances feed intake, feeding behavior, fish growth as well as improves the overall wellbeing and performance of the fish, as the result of hypoxia on the biological or metabolic actions of farmed fish would be negatively affected. A deep look into an article by Abdel-Tawwab and colleagues (72) gives more insight into the effects of hypoxia on fish growth and physiological activities.

\subsubsection{Photoperiod and Light Regime}

Photoperiod has been known to influence and manipulate some biological functioning in fish (83). Research conducted on several fish species have revealed that photoperiod and the light regime influence their feeding activities. Photoperiod plays a significant part in the growth and survival of fish, thus influencing its feed intake and feeding behavior (84). It is known to have the ability to affect the general wellbeing and routine of fish (85).

The requirements of photoperiod and light concentration in fish are species-specific and differ for the several developing phases (84). Consequently, whiles this could be related to fish species specificity, when photoperiod is appropriately applied, it may aid in an advanced performance of the fish, thereby improving the productivity and sustainability of aquacultural practices. For example, a research study conducted on catfish (Clarias gariepinus) fingerlings cultured under three different photoperiod conditions; 24 hours (hrs) darkness, 24hrs light and $12 / 12 \mathrm{hrs}$ darkness and light revealed that those cultured under 24 hrs of darkness had significantly highest feed intake, best feed conversion ratio and lowest quantity of uneaten feed as compared to those cultured under $24 \mathrm{hrs}$ light and 12/12 hrs of darkness and light (85). Also, in a research study on the pacamã catfish (Lophiosilurus alexandri), it was revealed that $24 \mathrm{hrs}$ continuous light led to the highest feed intake (86). Going more further, in research conducted on the sharp-snout seabream (Diplodus puntazzo) it was concluded that although feeding behavior was strictly diurnal, $97 \%$ of feed demands were made during the light periods (87). A detailed look into how photoperiod affects fish species feed intake and feeding behavior will be of much importance.

\subsubsection{Circannual and Circadian Rhythms}

All these external factors that impact the feeding behavior in fish have periodic or recurring styles. Thus, they affect food intake unswervingly via cyclical and or 24-hourly rhythms (88) or ramblingly through rhythms in endocrine systems $(89,90)$. All animals, even fish, showcase natural behavioral rhythms, including the two principal feed intake rhythms in fish; the daily (circadian) and seasonal (circannual) rhythms (23, 91, 92).

Several organisms including fish, exhibit annual rhythms in physiological and behavioral factors, such as feeding, reproduction, body weight, hibernation, and movement. These factors are controlled by oscillations in the secretion of hormones. The timing of these annual rhythms is delimited by changes in day length, photoperiod, or temperature, which makes available a reliable and predictive indicator of seasonal changes in environmental conditions (93). The circannual (seasonal) rhythms in vertebrates (fish) associate meticulously with ambient environmental factors, thus environmental (water) temperature and the length of the day. During the spring and summer seasons, when the days are longer and the temperature of water bodies is higher, several fish species increase their feed intake as well as their feeding behavior (23). There is limited information on how these seasonal or circannual rhythms influence feed ingestion and feeding behavior in fish, making it complex to give a straightforward conclusion about feeding activities and associated seasonal changes. As it stands now, we recommend that more research be conducted on fish feeding and feeding behavior regarding the impact of the circannual rhythms.

The circadian rhythm is a natural rhythm that is regulated by a biological daily clock that proceeds in a steady setting. This biological clock is a 24-hour cycle in the biochemical, physiological, or behavioral processes of a live organism geared for maximizing cellular activities and recognizing solar day-related environmental obstacles (94). The 24-hourly rotations of behavior and physiology (example; feeding activity) have been established in all classes of craniates, including some fish species $(95,96)$. Several inward or endogenic clocks prompt these circadian cycles. They consist of an independent transcriptional-translational response grummet that encompasses the recurring circadian-regulative genes expression (97) and perseveres under continuous extrinsic circumstances, such as photoperiod (98).

As in many animals, fish species consume meals at specific times during the day or night. That is to say that in fish circadian rhythms, the natural daily food ingestion times differ among species (90). Some classify specifically as daytime feeders such as Atlantic salmon, Salmo salar (99), redbelly tilapia (Tilapia zillii) (100) rohu (Labeo rohita), and common carp (Cyprinus carpio) (101) whiles others are described as night time feeders, example; European catfish (Silurus glanis) (102) and Zebrafish (Danio rerio) (103). Additionally, several fish species have showcased ideal times of eating daily (day or night). For example, research 
studies conducted on goldfish (Carassius auratus) and rainbow trout (Oncorhynchus mykiss) respectively revealed that the intake of food and the composition of the body is influenced by the time a single daily meal is delivered (104) whiles rainbow trout (Oncorhynchus mykiss) fed during their habitual or natural eating times have higher feed efficiency (105).

There are approximately a handful of known genes or hormones which regulate feed intake in fish species, including neuropeptide Y, peptide YY, ghrelin, galanin, apelin, among others. These appetite-regulating genes influence the intake of feed in two ways; feed intake inducer or inhibitor. The appetiteinducing hormones persuade or signal hunger in fish, thus causing them to search for food to eat (orexigenic factor). On the other hand, appetite-inhibiting hormones are the hormones in fish that signal their satisfaction (anorexigenic factor). Several external and internal factors affect the display of this physiological role in feed intake regulation in fish with regards to their specificity (106). As such, these factors regulate the roles of the gene either by playing opposite roles or not affect the fish at appropriate times (50). Below, we elaborate more and present summaries of the results of research findings on apelin as an appetite-regulating hormone in fish.

\section{APELIN AND ITS PHYSIOLOGICAL ROLE IN REGULATING FEED INTAKE IN FISH}

\subsection{Isolation and Characteristics of Apelin}

Apelin is a 36-amino acid (AA) peptide that was initially isolated from bovine stomach extracts (107). It is a recently discovered peptide known as a ligand for the APJ receptor, a putative receptor protein related to the type- 1 angiotensin receptor, and a member of the family of seven transmembrane domains G-protein-coupled receptors (GPCRs) $(108,109)$. From the findings of researches conducted by the research teams of Langelaan and Malyszko, it revealed in mammals that, a 77 AA precursor, prepro-apelin, gives rise to numerous forms of apelin, which can be composed of 13-36 AA residues (110, 111), thus 36, apelin-17, and apelin-13 (112).

The apelin receptor, also called APJ or angiotensin receptor-like1 which is currently known as the common receptor for apelin was primarily cloned in 1993 due to its robust sequence homology with the angiotensin II receptor (AT1) (54\% in transmembrane spheres and $31 \%$ for the complete sequence) but APJ does not bind angiotensin II (113). It is known to be an orphan G-proteincoupled receptor that was originally secluded from a human genomic collection using the polymerase chain reaction (PCR) (113). Apelin which was originally described as an endogenous ligand for APJ as stated by (107) secreted as a 77 amino acid forerunner, prepro-apelin, which is differentially processed producing numerous smaller peptide fragments, which comprises apelin-12, apelin-13, apelin-17, and apelin-36 (107, 114, 115).

\section{2 mRNA Expression of Apelin in Fish Tissues}

Several research studies have revealed the presence of the apelin gene (apelin) in several tissues of some fish species such as the goldfish (Carassius auratus) red-bellied piranha (Pygocentrus nattereri) and cunner (Tautogolabrus adspersus) these include different brain regions such as the ladder, optic tectum/thalamus, olfactory bulbs, and the hypothalamus. It can also be found in the pituitary, as well as the peripheral tissues in the fish; spleen, kidney, liver; muscle, brain, gut, gonad, gill, and heart, with seemingly higher expression levels in spleen, kidney, brain, gonad, gill, and heart $(19,116,117)$. Although weakly expressed, apelin was also identified in the hepatopancreas, eye, intestine, and skin of the Ya-fish (Schizothorax prenanti) (118). Also, in Schizothorax davidi, apelin mRNA was expressed in the spleen and heart, considerable levels in the brain (myelencephalon and telencephalon), liver, and trunk kidney (119), and pirapitinga, Piaractus brachypomus, apelin mRNA expression was revealed in the liver, stomach, pyloric caeca, foregut, hindgut, kidney, gill, skin, and muscle as well as in the brain and pituitary (117).

\subsection{Non-Appetite Regulatory Role of Apelin}

Apelin is known to control cardiovascular functions in mammals, including blood pressure and blood flow (109). The apelin/apj system plays important and several roles in the physiology and pathophysiology of many organs, including the regulation of blood pressure (120), cardiac contractility (121, 122), among others. It is known to be one of the most effective stimulators of cardiac contractility yet discovered and plays a role in cardiac tissue renovation in vertebrates (123-125).

\subsection{Apelin as an Appetite-Regulating Hormone in Fish}

Apelin, which has an uncertain role in the regulation of feeding in mammals is known to act as an orexigenic factor and might have several biological regulating roles in fish $(19,119,126)$. Either its peripheral and/or central injections increased food intake in fish species that have been studied. For example; research conducted on the blind cavefish, Astyanax fasciatus mexicanus revealed that peripheral injection of apelin significantly increased food intake of the fish as compared to saline injections (127). In goldfish (Carassius auratus) both intraperitoneal (i.p.) and intracerebroventricular (i.c.v.) injection of apelin-13 revealed an augmentation of its food intake (19). Also, in the Siberian sturgeon (Acipenser baerii) continuous i.p. injection of apelin demonstrated an increase in feed ingestion (126). Additionally, apelin i.p. injection in Ya-fish (Schizothorax prenanti) also stimulated the intake of feed (118).

\subsection{The Response of Apelin to Fasting and Refeeding in Fish}

Several hormones in fish as in other vertebrates control the intake of food. These hormones, known as appetite-regulating hormones are produced from the brain and or other marginal tissues in the body of the fish (50). These appetite-regulating hormones play roles either as a food inducer or inhibitor. Apelin's role on food intake in vertebrates like teleost is poorly understood (118). Nonetheless, researches have been conducted 
to find out the role that apelin plays in some fish species' food intake, either as an orexigenic or an anorexigenic indicator. Here, we elaborate more on its response to feeding and fasting, indicating which role it fits well into.

Research conducted on common carp (Cyprinus carpio) discovered that starvation resulted in a significant upsurge in hypothalamus apelin and expression of APJa mRNA. It then returned to normal levels after the fish were refed. Also, the expression of $A P J b$ mRNA augmented after temporary starvation, thus within 2 and 4 days; nevertheless, there was no significant difference between fed fish and refed fish even after the starvation was prolonged. From this same research, there was a significant increase in apelin, $A P J a$, and $A P J b$ mRNA expression levels in the foregut of the common carp, which then returned to normal levels after refeeding, either after a short-term or long-term fast (128). It was discovered from a research study that the abundance levels of apelin mRNA were greater in starved goldfish than in fed goldfish (Carassius auratus) in both hypothalamus and telencephalon (19). Another research study also revealed that apelin mRNA levels in the whole brain were higher at $1 \mathrm{hr}$ after feeding than that of unfed Siberian sturgeon (Acipenser baerii). However, its expression returned to normal levels at $3 \mathrm{hrs}$ after feeding (126). In this same research study, it was revealed that apelin has bidirectional effects on feeding regulation in the Siberian sturgeon (Acipenser baerii) thus, apelin acts as a satiety factor in the short-term feeding regulation and a hunger factor in longterm feeding regulation (126). Moreover, in research conducted on Schizothorax davidi, it was concluded that apelin expression of fed fish at $+1 \mathrm{hr}$ and $+3 \mathrm{hrs}$ after feeding was lower than that of unfed fish, and apelin expression in the hypothalamus of unfed fish augmented on the 5th and 7th days and when fasting fish were re-fed, apelin mRNA expressions disclosed a notable decrease from the 9 th to the 14th day concerning the fed group (119). Furthermore, in the red-bellied piranha (Pygocentrus nattereri) fasting induced a significant increase in the mRNA expression of apelin in the brain (129).

Research conducted on Ya-fish (Schizothorax prenanti) revealed that there was about 2.5 and a 2-fold decrease in apelin mRNA expression in the hypothalamus of fed fish at 1 $\mathrm{hr}$ and $3 \mathrm{hrs}$ post-feeding compared to unfed controls, respectively (118). Both the levels of apelin and APJ mRNA expressions had a decreasing trend hours before feeding. In this same research, concerning food deprivation, food-destitute Yafish (Schizothorax prenanti) had a noteworthy change of about 1.8-fold higher mRNA expression levels of apelin than 3, 5 and 7 days habitually fed controls. The mRNA expression of apelin was significantly decreased when 7-day fasted Ya-fish (Schizothorax prenanti) were re-fed, and the levels of the 7-day fed control group and fasted group of Ya-fish (Schizothorax prenanti) had an about 1.5- and 2.5-fold higher than the 7-day refed fish, respectively.

To sum up, the role of apelin is highly attributable to appetite regulation in fish. That is to say, the apelin hormone in starved or unfed fish induces hunger (up-regulated) and thus, persuades the fish to go after or search for its meal and there's a gradual or complete decrease in the expression of apelin as the fish eats or post-eating. A referral to Figure $\mathbf{1}$ in an article publish by Assan and colleagues (50) gives a clear clue on the existing relationship between appetite-inducing genes and appetite-inhibiting genes.

Table 1 summarizes fish that have been used as models for apelin research studies as appetite-regulating factors.

\subsection{The Interactions of Apelin With Other Appetite-Inducing Hormones in Fish}

Recent researches have demonstrated that individual orexigenic molecules or hormones interact with each other. For example, in cavefish, Astyanax fasciatus mexicanus, apelin i.p. injections increased orexin brain expression but did not affect either cholecystokinin or cocaine- and amphetamine-regulated transcript expression, suggesting that apelin might increase food intake through the stimulation of the orexin system in cavefish (127). Additionally, it was demonstrated by in vitro and in vivo experiments that apelin could persuade important mRNA expression levels of appetite-related and growth-related genes, including neuropeptide $Y$, agouti-related peptide, and orexin. This suggests that apelin has the potential to control the food intake and development of common carp by regulating the expression of these vital genes (130).

\subsection{Characteristic Similarities Within Appetite-Regulating Hormones}

Besides the fish-species-specificity and other intrinsic and extrinsic factors antagonizing appetite-regulating hormones from exerting their full function on regulating feeding in

TABLE 1 | Summary of fish used as models to identify apelin as an appetiteregulating hormone.

\begin{tabular}{|c|c|c|c|c|c|}
\hline Fish models & Treatment & $\begin{array}{c}\text { Duration } \\
\text { of treat- } \\
\text { ment }\end{array}$ & $\begin{array}{c}\text { Gene reg- } \\
\text { ulation }\end{array}$ & $\begin{array}{c}\text { Tissues with } \\
\text { the highest } \\
\text { mRNA } \\
\text { expression }\end{array}$ & Reference \\
\hline $\begin{array}{l}\text { Ya-fish } \\
\text { (Schizothorax } \\
\text { prenanti) }\end{array}$ & Starvation & 7 days & $\begin{array}{l}\text { Up- } \\
\text { regulation }\end{array}$ & $\begin{array}{l}\text { Heart, spleen, } \\
\text { hypothalamus } \\
\text { and kidney }\end{array}$ & (118) \\
\hline $\begin{array}{l}\text { Common } \\
\text { carp } \\
\text { (Cyprinus } \\
\text { carpio) }\end{array}$ & & 8 days & & $\begin{array}{l}\text { Brain, } \\
\text { pituitary } \\
\text { gland, spleen, } \\
\text { and kidney }\end{array}$ & (128) \\
\hline $\begin{array}{l}\text { Goldfish } \\
\text { (Carassius } \\
\text { auratus) }\end{array}$ & & 7 days & & $\begin{array}{l}\text { Spleen, } \\
\text { kidney, brain, } \\
\text { gonad, gill, } \\
\text { and heart }\end{array}$ & (19) \\
\hline $\begin{array}{l}\text { Siberian } \\
\text { sturgeon } \\
\text { (Acipenser } \\
\text { baerii) }\end{array}$ & & 15 days & & $\begin{array}{l}\text { Brain, spleen, } \\
\text { stomach, and } \\
\text { kidney }\end{array}$ & (126) \\
\hline $\begin{array}{l}\text { Red-bellied } \\
\text { piranha } \\
\text { (Pygocentrus } \\
\text { nattereri) }\end{array}$ & & 7 days & & $\begin{array}{l}\text { Spleen, } \\
\text { kidney, heart, } \\
\text { and brain }\end{array}$ & (129) \\
\hline $\begin{array}{l}\text { Schizothorax } \\
\text { davidi }\end{array}$ & & 14 days & & $\begin{array}{l}\text { Brain, heart, } \\
\text { spleen, liver, } \\
\text { and trunk } \\
\text { kidney }\end{array}$ & (119) \\
\hline
\end{tabular}


TABLE 2 | List of other known appetite-inducing hormones in fish.

\begin{tabular}{llc}
\hline Other appetite-inducing hormones & Key expressed tissue & Reference \\
\hline Ghrelin & Gastrointestinal tract & $(131,132)$ \\
Neuropeptide Y & Brain/Gastrointestinal tract & $(12,18)$ \\
Agouti Related Protein & Brain & $(12,133)$ \\
Orexins & Brain & $(12,134)$ \\
Galanin & Brain & $(135,136)$ \\
Growth hormone & Pituitary & $(137)$ \\
\hline
\end{tabular}

teleost and other fish species, other genes play the same specific role in feed regulation in fish as apelin does. See Table 2 for a list of other appetite-inducing hormones in fish.

Generally, appetite-inducing hormones (hunger or orexigenic hormones) serve as hunger signals, causing an increase in feed ingestion. That is to say, fasting or starvation causes an upregulation of these appetite-inducing hormones in fish, for example; ghrelin $(131,132)$, neuropeptide $Y$ and orexin $(12,18)$. On the other hand, appetite-inhibiting hormones (satiety or anorexigenic hormones) cause a reduction in food intake, thus fasting or starvation does not affect their expression but rather feed intake causes an up-regulation of these appetite-inducing hormones. Thus, appetite-inhibiting hormones in fish demonstrate pre-prandial decreases and postprandial increases in their concentrations. Example; peptide YY (50), cholecystokinin (138), and cocaine- and amphetamine-regulated transcript (20).

It has been demonstrated that the peripheral or central orexigenic hormone injections in fish persuade a significantly increase in food consumption rate as indicated in some research studies $(15,118,126,127,139)$. Also, experiments demonstrating the acute and or chronic effect of anorexigenic hormone injections on either peripheral tissues or the brain of some fish species revealed that there were significant reductions in food ingestion for a short period in the acute and a long period all through the whole experiment for the chronic injection. Examples of such experiments include those conducted by $(127,140)$.

\section{CONCLUSION}

Data available on fish feeding regulations indicate that the fundamental mechanisms in regulating feeding behavior are conserved. Our knowledge about how extrinsic factors influence feed ingestion and feeding behavior has been simplified. However, it appears that the general scheme of feeding regulation in fishes is similar to that of other vertebrates in the sense that hunger and feeding are controlled by central feeding centers that are influenced by endocrine

\section{REFERENCES}

1. Volkoff H, Hoskins LJ, Tuziak SM. Influence of Intrinsic Signals and Environmental Cues on the Endocrine Control of Feeding in Fish: Potential Application in Aquaculture. Gen Comp Endocrinol (2010) 167:352-9. doi: 10.1016/j.ygcen.2009.09.001 factors rising from both the brain or from marginal tissues. As a whole, we believe there is still limited information available in fish compared with other organisms regarding how these extrinsic factors influence fish feeding and feeding response.

The role of apelin is highly attributable to appetite regulation in fish species that have been studied. To date, most researches conducted on appetite-regulating hormones in fish species have been relatively short-term studies, thus, making it difficult to establish a relation between short-term and long-term appetiterelated factors. Fish have been known to exhibit a wider range of feeding behaviors, feeding habits, and feeding adaptations, including fasting or starvation periods. Here we suggest research to be advanced on the mechanisms regulating feeding and appetite-regulating hormones and genes in fish. Also, research on the response of apelin to feeding, fasting, and refeeding should be conducted based on the influence of these extrinsic factors, adding up to the existing studies.

\section{AUTHOR CONTRIBUTIONS}

DA designed the content and structure of the whole paper. UFM designed the figures. DA, YH, UFM, and MA wrote the review. GL and HC proofread and revised the paper. All authors contributed to the article and approved the submitted version.

\section{FUNDING}

This article was supported by grants from the Key Research and Development Program of Guangdong (2021B202020002), the Guangdong Basic and Applied Basic Research Foundation (2019A1515010958 and 2019A1515012042), the Southern Marine Science and Engineering Guangdong Laboratory (Zhanjiang) (ZJW-2019-06), The Open Project of the Key Laboratory of Utilization and Protection of Tropical Marine Biological Resources (Hainan Tropical Ocean University), the Ministry of Education (grant number UCTMB20201), and Guangdong South China Sea Key Laboratory of Aquaculture for Aquatic Economic Animals, Guangdong Ocean University (No. KFKT2019ZD07).

\section{ACKNOWLEDGMENTS}

We are thankful to the researchers whose contributions have been cited in this review paper, which have helped us to prepare a constructive review. Moreover, we apologize to those authors whose admirable work could not be cited due to space limitations.

2. Metcalfe NB, Huntingford FA, Thorpe JE. Seasonal Changes in Feeding Motivation of Juvenile Atlantic Salmon (Salmo Salar). Can J Zool (1986) 64:2439-46. doi: 10.1139/z86-364

3. Volkoff H. The Neuroendocrine Regulation of Food Intake in Fish: A Review of Current Knowledge. Front Neurosci (2016) 10:540. doi: 10.3389/ fnins.2016.00540 
4. Delgado MJ, Cerdá-Reverter JM, Soengas JL. Hypothalamic Integration of Metabolic, Endocrine, and Circadian Signals in Fish: Involvement in the Control of Food Intake. Front Neurosci (2017) 11:354. doi: 10.3389/ fnins.2017.00354

5. Sunter D, Hewson AK, Dickson SL. Intracerebroventricular Injection of Apelin-13 Reduces Food Intake in the Rat. Neurosci Lett (2003) 353:1-4. doi: 10.1016/S0304-3940(03)00351-3

6. Hoskins LJ, Volkoff H. The Comparative Endocrinology of Feeding in Fish: Insights and Challenges. Gen Comp Endocrinol (2012) 176:327-35. doi: 10.1016/j.ygcen.2011.12.025

7. Sobrino Crespo C, Perianes Cachero A, Puebla Jiménez L, Barrios V, Arilla Ferreiro E. Peptides and Food Intake. Front Endocrinol (2014) 5:58. doi: $10.3389 /$ fendo.2014.00058

8. Conde-Sieira M, Soengas JL. Nutrient Sensing Systems in Fish: Impact on Food Intake Regulation and Energy Homeostasis. Front Neurosci (2017) 10:603. doi: 10.3389/fnins.2016.00603

9. Bertucci JI, Blanco AM, Sundarrajan L, Rajeswari JJ, Velasco C, Unniappan S. Nutrient Regulation of Endocrine Factors Influencing Feeding and Growth in Fish. Front Endocrinol (Lausanne) (2019) 10:83. doi: 10.3389/ fendo.2019.00083

10. Campos VF, Robaldo RB, Deschamps JC, Seixas FK, McBride AJA, Marins LF, et al. Neuropeptide Y Gene Expression Around Meal Time in the Brazilian Flounder Paralichthys Orbignyanus. J Biosci (2012) 37:227-32. doi: 10.1007/s12038-012-9205-7

11. Wall A, Volkoff H. Effects of Fasting and Feeding on the Brain mRNA Expressions of Orexin, Tyrosine Hydroxylase (TH), PYY and CCK in the Mexican Blind Cavefish (Astyanax Fasciatus Mexicanus). Gen Comp Endocrinol (2013) 183:44-52. doi: 10.1016/j.ygcen.2012.12.011

12. Volkoff H, Sabioni RE, Cyrino JEP. Appetite Regulating Factors in Dourado, Salminus Brasiliensis: cDNA Cloning and Effects of Fasting and Feeding on Gene Expression. Gen Comp Endocrinol (2016) 237:34-42. doi: 10.1016/ j.ygcen.2016.07.022

13. Volkoff H, Sabioni RE, Coutinho LL, Cyrino JEP. Appetite Regulating Factors in Pacu (Piaractus Mesopotamicus): Tissue Distribution and Effects of Food Quantity and Quality on Gene Expression. Comp Biochem Physiol Part A Mol Integr Physiol (2017) 203:241-54. doi: 10.1016/j.cbpa.2016.09.022

14. Kuz'mina VV. The Regulatory Mechanisms of Feeding Behavior in Fish. J Evol Biochem Physiol (2019) 55:1-13. doi: 10.1134/S0022093019010010

15. Volkoff H, Unniappan S, Kelly SP. The Endocrine Regulation of Food Intake. Fish Physiol (2009) 28:421-65. doi: 10.1016/S1546-5098(09)28009-5

16. Conde-Sieira M, Aguilar AJ, López-Patiño MA, Míguez JM, Soengas JL. Stress Alters Food Intake and Glucosensing Response in Hypothalamus, Hindbrain, Liver, and Brockmann Bodies of Rainbow Trout. Physiol Behav (2010) 101:483-93. doi: 10.1016/j.physbeh.2010.07.016

17. Lin X, Volkoff H, Narnaware Y, Bernier NJ, Peyon P, Peter RE. Brain Regulation of Feeding Behavior and Food Intake in Fish. Comp Biochem Physiol Part A Mol Integr Physiol (2000) 126:415-34. doi: 10.1016/S10956433(00)00230-0

18. Aldegunde M, Mancebo M. Effects of Neuropeptide $\mathrm{Y}$ on Food Intake and Brain Biogenic Amines in the Rainbow Trout (Oncorhynchus Mykiss). Peptides (2006) 27:719-27. doi: 10.1016/j.peptides.2005.09.014

19. Volkoff H, Wyatt JL. Apelin in Goldfish (Carassius Auratus): Cloning, Distribution and Role in Appetite Regulation. Peptides (2009) 30:1434-40. doi: 10.1016/j.peptides.2009.04.020

20. Volkoff H, Peter RE. Characterization of Two Forms of Cocaine-and Amphetamine-Regulated Transcript (CART) Peptide Precursors in Goldfish: Molecular Cloning and Distribution, Modulation of Expression by Nutritional Status, and Interactions With Leptin. Endocrinology (2001) 142:5076-88. doi: 10.1210/endo.142.12.8519

21. Thavanathan R, Volkoff H. Effects of Amylin on Feeding of Goldfish: Interactions With CCK. Regul Pept (2006) 133:90-6. doi: 10.1016/ j.regpep.2005.09.025

22. Houlihan D, Boujard T, Jobling M. Food Intake in Fish. Oxford: Blackwell Science (2001).

23. Gerking SD. Feeding Ecology of Fish. Elsevier (2014).

24. Lall SP, Tibbetts SM. Nutrition, Feeding, and Behavior of Fish. Vet Clin North Am Exot Anim Pract (2009) 12:361-72. doi: 10.1016/j.cvex. 2009.01.005
25. Badman MK, Flier JS. The Gut and Energy Balance: Visceral Allies in the Obesity Wars. Science (80- ) (2005) 307:1909-14. doi: 10.1126/science.1109951

26. Simpson SJ, Raubenheimer D. A Framework for the Study of Macronutrient Intake in Fish. Aquac Res (2001) 32:421-32. doi: 10.1046/j.13652109.2001.00593.x

27. da Silva RF, Kitagawa A, Sánchez Vázquez FJ. Dietary Self-Selection in Fish: A New Approach to Studying Fish Nutrition and Feeding Behavior. Rev Fish Biol Fish (2016) 26:39-51. doi: 10.1007/s11160-015-9410-1

28. Almaida-Pagán PF, Rubio VC, Mendiola P, De Costa J, Madrid JA. Macronutrient Selection Through Post-Ingestive Signals in Sharpsnout Seabream Fed Gelatine Capsules and Challenged With Protein Dilution. Physiol Behav (2006) 88:550-8. doi: 10.1016/j.physbeh.2006.05.027

29. Rubio VC, Boluda Navarro D, Madrid JA, Sánchez-Vázquez FJ. Macronutrient Self-Selection in Solea Senegalensis Fed Macronutrient Diets and Challenged With Dietary Protein Dilutions. Aquaculture (2009) 291:95-100. doi: 10.1016/j.aquaculture.2009.02.040

30. Zhou C, Xu D, Lin K, Sun C, Yang X. Intelligent Feeding Control Methods in Aquaculture With an Emphasis on Fish: A Review. Rev Aquac (2018) 10:975-93. doi: 10.1111/raq.12218

31. Efeyan A, Comb WC, Sabatini DM. Nutrient-Sensing Mechanisms and Pathways. Nature (2015) 517:302-10. doi: 10.1038/nature14190

32. Kestemont P, Baras E. Environmental Factors and Feed Intake: Mechanisms and Interactions. Food Intake Fish (2001) 131-56. doi: 10.1002/ 9780470999516.ch6

33. Freeman DW. Using the NRC to Manage Horse Nutrition (An Overview of Management Issues in the Nutrient Requirements of Horses. In: Conference Sponsors (Citeseer), vol. 171. Washington DC: The National Academic Press. (2007).

34. NRC, N. R. C. Nutrient Requirements of Fish and Shrimp. Washington, DC: National academies press (2011).

35. Li P, Mai K, Trushenski J, Wu G. New Developments in Fish Amino Acid Nutrition: Towards Functional and Environmentally Oriented Aquafeeds. Amino Acids (2009) 37:43-53. doi: 10.1007/s00726-008-0171-1

36. Sheridan MA. Regulation of Lipid Metabolism in Poikilothermic Vertebrates. Comp Biochem Physiol Part B Comp Biochem (1994) 107:495-508. doi: 10.1016/0305-0491(94)90176-7

37. Tocher DR. Metabolism and Functions of Lipids and Fatty Acids in Teleost Fish. Rev Fish Sci (2003) 11:107-84. doi: 10.1080/713610925

38. Borges P, Oliveira B, Casal S, Dias J, Conceiçao L, Valente LMP. Dietary Lipid Level Affects Growth Performance and Nutrient Utilisation of Senegalese Sole (Solea Senegalensis) Juveniles. Br J Nutr (2009) 102:100714. doi: $10.1017 /$ S0007114509345262

39. Soengas JL, Aldegunde M. Energy Metabolism of Fish Brain. Comp Biochem Physiol Part B Biochem Mol Biol (2002) 131:271-96. doi: 10.1016/S10964959(02)00022-2

40. Soengas JL. Contribution of Glucose-and Fatty Acid Sensing Systems to the Regulation of Food Intake in Fish. A Review. Gen Comp Endocrinol (2014) 205:36-48. doi: 10.1016/j.ygcen.2014.01.015

41. Craig S, Helfrich LA. Understanding Fish Nutrition, Feeds and Feeding, Cooperative Extension Service, Publication 420-256. Virginia State Univ USA (2002). 26-7.

42. Eriegha OJ, Ekokotu PA. Factors Affecting Feed Intake in Cultured Fish Species: A Review. Anim Res Int (2017) 14:2697-709.

43. Hepher B. Nutrition of Pond Fishes. Cambridge university press (1988).

44. Omitoyin BO. Introduction to Fish Farming in Nigeria. Ibadan, Nigeria: Ibadan University Press (2007).

45. Yamamoto T, Shima T, Furuita H, Suzuki N, Sánchez-Vázquez FJ, Tabata M. Self-Selection and Feed Consumption of Diets With a Complete Amino Acid Composition and a Composition Deficient in Either Methionine or Lysine by Rainbow Trout, Oncorhynchus Mykiss (Walbaum). Aquac Res (2001) 32:83-91. doi: 10.1046/j.1355-557x.2001.00007.x

46. Vivas M, Rubio VC, Sánchez-Vázquez FJ, Mena C, García García B, Madrid JA. Dietary Self-Selection in Sharpsnout Seabream (Diplodus Puntazzo) Fed Paired Macronutrient Feeds and Challenged With Protein Dilution. Aquaculture (2006) 251:430-7. doi: 10.1016/j.aquaculture.2005.06.013

47. Aranda A, Sánchez-Vázquez FJ, Zamora S, Madrid JA. Self-Design of Fish Diets by Means of Self-Feeders: Validation of Procedures. J Physiol Biochem (2000) 56:155-66. doi: 10.1007/BF03179782 
48. Fortes-Silva R, Rosa PV, Zamora S, Sánchez-Vázquez FJ. Dietary SelfSelection of Protein-Unbalanced Diets Supplemented With Three Essential Amino Acids in Nile Tilapia. Physiol Behav (2012) 105:639-44. doi: 10.1016/j.physbeh.2011.09.023

49. van de Pol I, Flik G, Gorissen M. Comparative Physiology of Energy Metabolism: Fishing for Endocrine Signals in the Early Vertebrate Pool. Front Endocrinol (2017) 8:36. doi: 10.3389/fendo.2017.00036

50. Assan D, Mustapha UF, Chen H, Li Z, Peng Y, Li G. The Roles of Neuropeptide Y (Npy) and Peptide YY (Pyy) in Teleost Food Intake: A Mini Review. Life (2021) 11(6):547. doi: 10.3390/life11060547

51. Ramsay JM, Feist GW, Varga ZM, Westerfield M, Kent ML, Schreck CB. Whole-Body Cortisol Response of Zebrafish to Acute Net Handling Stress. Aquaculture (2009) 297:157-62. doi: 10.1016/j.aquaculture.2009.08.035

52. Aluru N, Vijayan MM. Stress Transcriptomics in Fish: A Role for Genomic Cortisol Signaling. Gen Comp Endocrinol (2009) 164:142-50. doi: 10.1016/ j.ygcen.2009.03.020

53. Wendelaar Bonga SE. The Stress Response in Fish. Physiol Rev (1997) 77:591-625. doi: 10.1152/physrev.1997.77.3.591

54. Bernier NJ. The Corticotropin-Releasing Factor System as a Mediator of the Appetite-Suppressing Effects of Stress in Fish. Gen Comp Endocrinol (2006) 146:45-55. doi: 10.1016/j.ygcen.2005.11.016

55. Beitinger TL. Behavioral Reactions for the Assessment of Stress in Fishes. J Great Lakes Res (1990) 16:495-528. doi: 10.1016/S0380-1330(90)71443-8

56. Conde-Sieira M, Chivite M, Míguez JM, Soengas JL. Stress Effects on the Mechanisms Regulating Appetite in Teleost Fish. Front Endocrinol (2018) 9:631. doi: 10.3389/fendo.2018.00631

57. Paspatis M, Boujard T, Maragoudaki D, Blanchard G, Kentouri M. Do Stocking Density and Feed Reward Level Affect Growth and Feeding of SelfFed Juvenile European Sea Bass? Aquaculture (2003) 216:103-13. doi: 10.1016/S0044-8486(02)00417-9

58. d'Orbcastel ER, Lemarié G, Breuil G, Petochi T, Marino G, Triplet S, et al. Effects of Rearing Density on Sea Bass (Dicentrarchus Labrax) Biological Performance, Blood Parameters and Disease Resistance in a Flow Through System. Aquat Living Resour (2010) 23:109-17. doi: 10.1051/alr/2009056

59. Leal E, Fernández-Durán B, Guillot R, Ríos D, Cerdá-Reverter JM. StressInduced Effects on Feeding Behavior and Growth Performance of the Sea Bass (Dicentrarchus Labrax): A Self-Feeding Approach. J Comp Physiol B Biochem Syst Environ Physiol (2011) 181:1035-44. doi: 10.1007/s00360-011-0585-z

60. Rotllant J, Balm PHM, Pérez-Sánchez J, Wendelaar-Bonga SE, Tort L. Pituitary and Interrenal Function in Gilthead Sea Bream (Sparus Aurata L., Teleostei) After Handling and Confinement Stress. Gen Comp Endocrinol (2001) 121:333-42. doi: 10.1006/gcen.2001.7604

61. Deane EE, Woo NYS. Modulation of Fish Growth Hormone Levels by Salinity, Temperature, Pollutants and Aquaculture Related Stress: A Review. Rev Fish Biol Fish (2009) 19:97-120. doi: 10.1007/s11160-008-9091-0

62. Saera-Vila A, Calduch-Giner JA, Prunet P, Pérez-Sánchez J. Dynamics of Liver GH/IGF Axis and Selected Stress Markers in Juvenile Gilthead Sea Bream (Sparus Aurata) Exposed to Acute Confinement: Differential Stress Response of Growth Hormone Receptors. Comp Biochem Physiol Part A Mol Integr Physiol (2009) 154:197-203. doi: 10.1016/j.cbpa.2009.06.004

63. Kasumyan AO, DÖving KB. Taste Preferences in Fishes. Fish Fish (2003) 4:289-347. doi: 10.1046/j.1467-2979.2003.00121.x

64. Handeland SO, Imsland AK, Stefansson SO. The Effect of Temperature and Fish Size on Growth, Feed Intake, Food Conversion Efficiency and Stomach Evacuation Rate of Atlantic Salmon Post-Smolts. Aquaculture (2008) 283:36-42. doi: 10.1016/j.aquaculture.2008.06.042

65. Volkoff H, Rønnestad I. Effects of Temperature on Feeding and Digestive Processes in Fish. Temperature (2020) 7:307-20. doi: 10.1080/ 23328940.2020.1765950

66. Shafland PL, Pestrak JM. Lower Lethal Temperatures for Fourteen NonNative Fishes in Florida. Environ Biol Fishes (1982) 7:149-56. doi: 10.1007/ BF00001785

67. Kehoe AS, Volkoff H. The Effects of Temperature on Feeding and Expression of Two Appetite-Related Factors, Neuropeptide Y and Cocaine-and Amphetamine-Regulated Transcript, in Atlantic Cod, Gadus Morhua. J World Aquac Soc (2008) 39:790-6. doi: 10.1111/j.1749-7345.2008.00215.x

68. Jeon E-J, Kim B-H, Lee C-H, Lee Y-D. Response of Appetite-Related Genes in Relation to the Rearing Water Temperature in Red Spotted Grouper
(Epinephelus Akaara). Fish Aquat Sci (2020) 23:1-9. doi: 10.1186/s41240020-00150-1

69. Walberg E. Effect of Increased Water Temperature on Warm Water Fish Feeding Behavior and Habitat Use. J Undergrad Res Minnesota State Univ Mankato (2011) 11:13.

70. Mizanur RM, Yun H, Moniruzzaman M, Ferreira F, Kim K, Bai SC. Effects of Feeding Rate and Water Temperature on Growth and Body Composition of Juvenile Korean Rockfish, Sebastes Schlegeli (Hilgendorf 1880). Asian Australasian J Anim Sci (2014) 27:690. doi: 10.5713/ajas.2013.13508

71. Lv H-B, Ma Y, Hu C-T, Lin Q-Y, Yue J, Chen L-Q, et al. The Individual and Combined Effects of Hypoxia and High-Fat Diet Feeding on Nutrient Composition and Flesh Quality in Nile Tilapia (Oreochromis Niloticus). Food Chem (2021) 343:128479. doi: 10.1016/j.foodchem.2020.128479

72. Abdel-Tawwab M, Monier MN, Hoseinifar SH, Faggio C. Fish Response to Hypoxia Stress: Growth, Physiological, and Immunological Biomarkers. Fish Physiol Biochem (2019) 45:997-1013. doi: 10.1007/s10695-019-00614-9

73. Refaey MM, Li D, Tian X, Zhang Z, Zhang X, Li L, et al. High Stocking Density Alters Growth Performance, Blood Biochemistry, Intestinal Histology, and Muscle Quality of Channel Catfish Ictalurus Punctatus. Aquaculture (2018) 492:73-81. doi: 10.1016/j.aquaculture.2018.04.003

74. Roman MR, Brandt SB, Houde ED, Pierson JJ. Interactive Effects of Hypoxia and Temperature on Coastal Pelagic Zooplankton and Fish. Front Mar Sci (2019) 6:139. doi: 10.3389/fmars.2019.00139

75. Wu RSS, Zhou BS, Randall DJ, Woo NYS, Lam PKS. Aquatic Hypoxia Is an Endocrine Disruptor and Impairs Fish Reproduction. Environ Sci Technol (2003) 37:1137-41. doi: 10.1021/es0258327

76. Remen M, Oppedal F, Torgersen T, Imsland AK, Olsen RE. Effects of Cyclic Environmental Hypoxia on Physiology and Feed Intake of Post-Smolt Atlantic Salmon: Initial Responses and Acclimation. Aquaculture (2012) 326-329:148-55. doi: 10.1016/j.aquaculture.2011.11.036

77. Magnoni LJ, Eding E, Leguen I, Prunet P, Geurden I, Ozório ROA, et al. Hypoxia, But Not an Electrolyte-Imbalanced Diet, Reduces Feed Intake, Growth and Oxygen Consumption in Rainbow Trout (Oncorhynchus Mykiss). Sci Rep (2018) 8:4965. doi: 10.1038/s41598-018-23352-z

78. Abdel-Tawwab M, Hagras AE, Elbaghdady HAM, Monier MN. Effects of Dissolved Oxygen and Fish Size on Nile Tilapia, Oreochromis Niloticus (L.): Growth Performance, Whole-Body Composition, and Innate Immunity. Aquac Int (2015) 23:1261-74. doi: 10.1007/s10499-015-9882-y

79. Abdel-Tawwab M, Hagras AE, Elbaghdady HAM, Monier MN. Dissolved Oxygen Level and Stocking Density Effects on Growth, Feed Utilization, Physiology, and Innate Immunity of Nile Tilapia, Oreochromis Niloticus. J Appl Aquac (2014) 26:340-55. doi: 10.1080/10454438.2014.959830

80. Bernier NJ, Gorissen M, Flik G. Differential Effects of Chronic Hypoxia and Feed Restriction on the Expression of Leptin and Its Receptor, Food Intake Regulation and the Endocrine Stress Response in Common Carp. J Exp Biol (2012) 215:2273-82. doi: 10.1242/jeb.066183

81. Segner H, Sundh H, Buchmann K, Douxfils J, Sundell KS, Mathieu C, et al. Health of Farmed Fish: Its Relation to Fish Welfare and Its Utility as Welfare Indicator. Fish Physiol Biochem (2012) 38:85-105. doi: 10.1007/s10695-0119517-9

82. Cook DG, Herbert NA. The Physiological and Behavioural Response of Juvenile Kingfish (Seriola Lalandi) Differs Between Escapable and Inescapable Progressive Hypoxia. J Exp Mar Bio Ecol (2012) 413:138-44. doi: 10.1016/j.jembe.2011.12.006

83. Biswas AK, Takeuchi T. Effects of Photoperiod and Feeding Interval on Food Intake and Growth Rate of Nile Tilapia Oreochromis Niloticus L. Fish Sci (2003) 69:1010-6. doi: 10.1046/j.1444-2906.2003.00720.x

84. Nwosu BFM, Holzlöhner S. Effect of Light Periodicity and Intensity on the Growth and Survival of Heterobranchus Longifilis Val. 1840 (Teleostei: Clariidae) Larvae After 14 Days of Rearing. J Appl Ichthyol (2000) 16:24-6. doi: 10.1046/j.1439-0426.2000.00145.x

85. Adewolu MA, Adeniji CA, Adejobi AB. Feed Utilization, Growth and Survival of Clarias Gariepinus (Burchell 1822) Fingerlings Cultured Under Different Photoperiods. Aquaculture (2008) 283:64-7. doi: 10.1016/ j.aquaculture.2008.07.020

86. Kitagawa AT, Costa LS, Paulino RR, Luz RK, Rosa PV, Guerra-Santos B, et al. Feeding Behavior and the Effect of Photoperiod on the Performance and Hematological Parameters of the Pacamã Catfish (Lophiosilurus 
Alexandri). Appl Anim Behav Sci (2015) 171:211-8. doi: 10.1016/ j.applanim.2015.08.025

87. Vera LM, Madrid JA, Sanchez-Vazquez FJ. Locomotor, Feeding and Melatonin Daily Rhythms in Sharpsnout Seabream (Diplodus Puntazzo). Physiol Behav (2006) 88:167-72. doi: 10.1016/j.physbeh.2006.03.031

88. Kulczykowska E, Sánchez Vázquez FJ. Neurohormonal Regulation of Feed Intake and Response to Nutrients in Fish: Aspects of Feeding Rhythm and Stress. Aquac Res (2010) 41:654-67. doi: 10.1111/j.1365-2109.2009.02350.x

89. Cowan M, Azpeleta C, López-Olmeda JF. Rhythms in the Endocrine System of Fish: A Review. J Comp Physiol B (2017) 187:1057-89. doi: 10.1007/ s00360-017-1094-5

90. Isorna E, de Pedro N, Valenciano AI, Alonso-Gómez ÁL, Delgado MJ. Interplay Between the Endocrine and Circadian Systems in Fishes. J Endocrinol (2017) 232:R141-59. doi: 10.1530/JOE-16-0330

91. Boujard T, Leatherland JF. Circadian Rhythms and Feeding Time in Fishes. Environ Biol Fishes (1992) 35:109-31. doi: 10.1007/BF00002186

92. Bolliet V, Azzaydi M, Boujard T. Effects of Feeding Time on Feed Intake and Growth. Food Intake Fish (2001) 233-49. doi: 10.1002/9780470999516.ch10

93. Goldman BD. Mammalian Photoperiodic System: Formal Properties and Neuroendocrine Mechanisms of Photoperiodic Time Measurement. J Biol Rhythms (2001) 16:283-301. doi: 10.1177/074873001129001980

94. Al-Mousawi ZAH, Alallawee MHA, Ali SA. Circadian Rhythms and Hormonal Homeostasis in Animals : A Review. Basrah J Vet Res (2021) 20:128-37.

95. López-Olmeda JF, Sánchez-Vázquez FJ. Feeding Rhythms in Fish: From Behavioral to Molecular Approach. Biol Clock Fish (2010), 155-83. doi: 10.1201/b10170

96. Jobling M, Kadri S, Huntingford F, Alanärä A. Feeding Biology and Foraging. Aquac Behav (2012) 121-49. doi: 10.1002/9781444354614.ch5

97. Ishikawa T, Hirayama J, Kobayashi Y, Todo T. Zebrafish CRY Represses Transcription Mediated by CLOCK-BMAL Heterodimer Without Inhibiting Its Binding to DNA. Genes to Cells (2002) 7:1073-86. doi: 10.1046/j.13652443.2002.00579.x

98. Kojima S, Shingle DL, Green CB. Post-Transcriptional Control of Circadian Rhythms. J Cell Sci (2011) 124:311-20. doi: 10.1242/jcs.065771

99. Paspatis M, Boujard T. A Comparative Study of Automatic Feeding and SelfFeeding in Juvenile Atlantic Salmon (Salmo Salar) Fed Diets of Different Energy Levels. Aquaculture (1996) 145:245-57. doi: 10.1016/S0044-8486(96) 01336-1

100. Negassa A, Getahun A. Food Habits and Diel Feeding Rhythm of Introduced Fish, Tilapia Zillii Gervais 1948 (Pisces: Cichlidae) in Lake Zwai, Ethiopia. SINET Ethiop J Sci (2004) 27:9-16. doi: 10.4314/sinet.v27i1.18216

101. Rahman MM, Verdegem M, Wahab MA, Hossain MY, Jo Q. Effects of Day and Night on Swimming, Grazing and Social Behaviours of Rohu Labeo Rohita (Hamilton) and Common Carp Cyprinus Carpio (L.) in Simulated Ponds. Aquac Res (2008) 39:1383-92. doi: 10.1111/j.1365-2109.2008.02007.x

102. Boujard T. Diel Rhythms of Feeding Activity in the European Catfish, Silurus Glanis. Physiol Behav (1995) 58:641-5. doi: 10.1016/0031-9384(95)00109-V

103. del Pozo A, Sánchez-Férez JA, Sánchez-Vázquez FJ. Circadian Rhythms of Self-Feeding and Locomotor Activity in Zebrafish (Danio Rerio). Chronobiol Int (2011) 28:39-47. doi: 10.3109/07420528.2010.530728

104. Noeske TA, Spieler RE. Circadian Feeding Time Affects Growth of Fish. Trans Am Fish Soc (1984) 113:540-4. doi: 10.1577/1548-8659(1984)113<540: CFTAGO $>2.0 . \mathrm{CO} ; 2$

105. Gelineu A, Médale F, Boujard T. Effect of Feeding Time on Postprandial Nitrogen Excretion and Energy Expenditure in Rainbow Trout. J Fish Biol (1998) 52:655-64. doi: 10.1111/j.1095-8649.1998.tb00810.x

106. Rønnestad I, Gomes AS, Murashita K, Angotzi R, Jönsson E, Volkoff H. Appetite-Controlling Endocrine Systems in Teleosts. Front Endocrinol (2017) 8:73. doi: 10.3389/fendo.2017.00073

107. Tatemoto K, Hosoya M, Habata Y, Fujii R, Kakegawa T, Zou M-X, et al. Isolation and Characterization of a Novel Endogenous Peptide Ligand for the Human APJ Receptor. Biochem Biophys Res Commun (1998) 251:471-6. doi: 10.1006/bbrc. 1998.9489

108. Lee DK, Cheng R, Nguyen T, Fan T, Kariyawasam AP, Liu Y, et al. Characterization of Apelin, the Ligand for the APJ Receptor. J Neurochem (2000) 74:34-41. doi: 10.1046/j.1471-4159.2000.0740034.x

109. Llorens-Cortes C, Moos F. Opposite Potentiality of Hypothalamic Coexpressed Neuropeptides, Apelin and Vasopressin in Maintaining
Body-Fluid Homeostasis. Prog Brain Res (2008) 170:559-70. doi: 10.1016/ S0079-6123(08)00443-3

110. Malyszko J, Malyszko JS, Pawlak K, Mysliwiec M. Visfatin and Apelin, New Adipocytokines, and Their Relation to Endothelial Function in Patients With Chronic Renal Failure. Adv Med Sci (De Gruyter Open) (2008) 53:399-412. doi: 10.2478/v10039-008-0024-x

111. Langelaan DN, Bebbington EM, Reddy T, Rainey JK. Structural Insight Into G-Protein Coupled Receptor Binding by Apelin. Biochemistry (2009) 48:537-48. doi: 10.1021/bi801864b

112. Masri B, Knibiehler B, Audigier Y. Apelin Signalling: A Promising Pathway From Cloning to Pharmacology. Cell Signal (2005) 17:415-26. doi: 10.1016/ j.cellsig.2004.09.018

113. O’Dowd BF, Heiber M, Chan A, Heng HHQ, Tsui L-C, Kennedy JL, et al. A Human Gene That Shows Identity With the Gene Encoding the Angiotensin Receptor Is Located on Chromosome 11. Gene (1993) 136:355-60. doi: 10.1016/0378-1119(93)90495-O

114. Hosoya M, Kawamata Y, Fukusumi S, Fujii R, Habata Y, Hinuma S, et al. Molecular and Functional Characteristics of APJ Tissue Distribution of mRNA and Interaction With the Endogenous Ligand Apelin. J Biol Chem (2000) 275:21061-7. doi: 10.1074/jbc.M908417199

115. Kawamata Y, Habata Y, Fukusumi S, Hosoya M, Fujii R, Hinuma S, et al. Molecular Properties of Apelin: Tissue Distribution and Receptor Binding. Biochim Biophys Acta (BBA) Molecular Cell Res (2001) 1538:162-71. doi: 10.1016/S0167-4889(00)00143-9

116. Hayes J, Volkoff H. Characterization of the Endocrine, Digestive and Morphological Adjustments of the Intestine in Response to Food Deprivation and Torpor in Cunner, Tautogolabrus Adspersus. Comp Biochem Physiol Part A Mol Integr Physiol (2014) 170:46-59. doi: 10.1016/ j.cbpa.2014.01.014

117. Volkoff H. Cloning and Tissue Distribution of Appetite-Regulating Peptides in Pirapitinga (Piaractus Brachypomus). J Anim Physiol Anim Nutr (Berl) (2015) 99:987-1001. doi: 10.1111/jpn.12318

118. Lin $\mathrm{F}, \mathrm{Wu} \mathrm{H}$, Chen $\mathrm{H}$, Xin Z, Yuan D, Wang T, et al. Molecular and Physiological Evidences for the Role in Appetite Regulation of Apelin and Its Receptor APJ in Ya-Fish (Schizothorax Prenanti). Mol Cell Endocrinol (2014) 396:46-57. doi: 10.1016/j.mce.2014.08.009

119. Yuan D, Wang B, Tang T, Lei L, Zhou C, Li Z, et al. Characterization and Evaluation of the Tissue Distribution of CRH, Apelin, and GnRH2 Reveal Responses to Feeding States in Schizothorax Davidi. Fish Physiol Biochem (2021) 47:421-38. doi: 10.1007/s10695-020-00922-5

120. Chen MM, Ashley EA, Deng DXF, Tsalenko A, Deng A, Tabibiazar R, et al. Novel Role for the Potent Endogenous Inotrope Apelin in Human Cardiac Dysfunction. Circulation (2003) 108:1432-9. doi: 10.1161/01.CIR. 0000091235.94914.75

121. Gerbier R, Alvear-Perez R, Margathe J, Flahault A, Couvineau P, Gao J, et al. Development of Original Metabolically Stable Apelin-17 Analogs With Diuretic and Cardiovascular Effects. FASEB J (2017) 31:687-700. doi: 10.1096/fj.201600784R

122. Gunter S, Solomon A, Tsang L, Woodiwiss AJ, Robinson C, Millen AME, et al. Apelin Concentrations Are Associated With Altered Atherosclerotic Plaque Stability Mediator Levels and Atherosclerosis in Rheumatoid Arthritis. Atherosclerosis (2017) 256:75-81. doi: 10.1016/j.atherosclerosis.2016.11.024

123. Chandrasekaran B, Dar O, McDonagh T. The Role of Apelin in Cardiovascular Function and Heart Failure. Eur J Heart Fail (2008) 10:725-32. doi: 10.1016/j.ejheart.2008.06.002

124. Japp AG, Newby DE. The Apelin-APJ System in Heart Failure: Pathophysiologic Relevance and Therapeutic Potential. Biochem Pharmacol (2008) 75:1882-92. doi: 10.1016/j.bcp.2007.12.015

125. Ladeiras-Lopes R, Ferreira-Martins J, Leite-Moreira AF. The Apelinergic System: The Role Played in Human Physiology and Pathology and Potential Therapeutic Applications. Arq Bras Cardiol (2008) 90(5):343-9. doi: $10.1590 /$ s0066-782x2008000500012

126. Hao J, Liu Q, Zhang X, Wu Y, Zhu J, Qi J, et al. The Evidence of Apelin has the Bidirectional Effects on Feeding Regulation in Siberian Sturgeon (Acipenser Baerii). Peptides (2017) 94:78-85. doi: 10.1016/j.peptides.2017.05.007

127. Penney CC, Volkoff H. Peripheral Injections of Cholecystokinin, Apelin, Ghrelin and Orexin in Cavefish (Astyanax Fasciatus Mexicanus): Effects on Feeding and on the Brain Expression Levels of Tyrosine Hydroxylase, 
Mechanistic Target of Rapamycin and Appetite-Related Hormones. Gen Comp Endocrinol (2014) 196:34-40. doi: 10.1016/j.ygcen.2013.11.015

128. Yan X, Qin C, Deng D, Yang G, Feng J, Lu R, et al. Apelin and Apj in Common Carp (Cyprinus Carpio L.): Molecular Characterization, Tissue Expression and Responses to Periprandial Changes and Fasting-Refeeding. Aquac Res (2020) 51:1012-25. doi: 10.1111/are.14447

129. Volkoff H. Appetite Regulating Peptides in Red-Bellied Piranha, Pygocentrus Nattereri: Cloning, Tissue Distribution and Effect of Fasting on mRNA Expression Levels. Peptides (2014) 56:116-24. doi: 10.1016/j.peptides.2014.03.022

130. Yan X, Qin C, Yang G, Deng D, Yang L, Feng J, et al. The Regulatory Role of Apelin on the Appetite and Growth of Common Carp (Cyprinus Carpio L.). Animals (2020) 10:2163. doi: 10.3390/ani10112163

131. Unniappan S, Canosa LF, Peter RE. Orexigenic Actions of Ghrelin in Goldfish: Feeding-Induced Changes in Brain and Gut mRNA Expression and Serum Levels, and Responses to Central and Peripheral Injections. Neuroendocrinology (2004) 79:100-8. doi: 10.1159/000076634

132. Matsuda K, Miura T, Kaiya H, Maruyama K, Shimakura S-I, Uchiyama M, et al. Regulation of Food Intake by Acyl and Des-Acyl Ghrelins in the Goldfish. Peptides (2006) 27:2321-5. doi: 10.1016/j.peptides.2006.03.028

133. Cerdá-Reverter JM, Peter RE. Endogenous Melanocortin Antagonist in Fish: Structure, Brain Mapping, and Regulation by Fasting of the Goldfish AgoutiRelated Protein Gene. Endocrinology (2003) 144:4552-61. doi: 10.1210/ en.2003-0453

134. Hagan JJ, Leslie RA, Patel S, Evans ML, Wattam TA, Holmes S, et al. Orexin A Activates Locus Coeruleus Cell Firing and Increases Arousal in the Rat. Proc Natl Acad Sci (1999) 96:10911-6. doi: 10.1073/pnas.96.19.10911

135. de Pedro N, Céspedes MV, Delgado MJ, Alonso-Bedate M. The GalaninInduced Feeding Stimulation Is Mediated via $\alpha 2$-Adrenergic Receptors in Goldfish. Regul Pept (1995) 57:77-84. doi: 10.1016/0167-0115(95)91255-4

136. Volkoff H, Peter RE. Interactions Between Orexin A, NPY and Galanin in the Control of Food Intake of the Goldfish, Carassius Auratus. Regul Pept (2001) 101:59-72. doi: 10.1016/S0167-0115(01)00261-0
137. Johansson V, Winberg S, Björnsson BT. Growth Hormone-Induced Stimulation of Swimming and Feeding Behaviour of Rainbow Trout Is Abolished by the D1 Dopamine Antagonist SCH23390. Gen Comp Endocrinol (2005) 141:58-65. doi: 10.1016/j.ygcen.2004.11.014

138. Kurokawa T, Suzuki T, Hashimoto H. Identification of Gastrin and Multiple Cholecystokinin Genes in Teleost. Peptides (2003) 24:227-35. doi: 10.1016/ S0196-9781(03)00034-2

139. Yokobori E, Azuma M, Nishiguchi R, Kang KS, Kamijo M, Uchiyama M, et al. Neuropeptide Y Stimulates Food Intake in the Zebrafish, Danio Rerio. J Neuroendocrinol (2012) 24:766-73. doi: 10.1111/j.1365-2826.2012. 02281.x

140. Zhang X, Tang N, Qi J, Wang S, Hao J, Wu Y, et al. CCK Reduces the Food Intake Mainly Through CCK1R in Siberian Sturgeon (Acipenser Baerii Brandt). Sci Rep (2017) 7:1-13. doi: 10.1038/s41598-017-12646-3

Conflict of Interest: The authors declare that the research was conducted in the absence of any commercial or financial relationships that could be construed as a potential conflict of interest.

Publisher's Note: All claims expressed in this article are solely those of the authors and do not necessarily represent those of their affiliated organizations, or those of the publisher, the editors and the reviewers. Any product that may be evaluated in this article, or claim that may be made by its manufacturer, is not guaranteed or endorsed by the publisher.

Copyright (๑ 2021 Assan, Huang, Mustapha, Addah, Li and Chen. This is an openaccess article distributed under the terms of the Creative Commons Attribution License (CC BY). The use, distribution or reproduction in other forums is permitted, provided the original author(s) and the copyright owner(s) are credited and that the original publication in this journal is cited, in accordance with accepted academic practice. No use, distribution or reproduction is permitted which does not comply with these terms. 